CORRECTION

\title{
Correction: Idelalisib exposure before allogeneic stem cell transplantation in patients with follicular lymphoma: an EBMT
}

\section{survey}

Leopold Sellner (D), Johannes Schetelig (D), Linda Koster, Goda Choi, Didier Blaise (D), Dietrich Beelen, Fabrizio Carnevale Schianca, Jakob Passweg, Urs Schanz, Emmanuel Gyan, Federica Sora, Nicolaus Kröger, Gerald. G. Wulf, Gwendolyn Van Gorkom, Jiri Mayer, Corentin Orvain, Jean Henri Bourhis, Pavel Jindra (D), Victoria Potter, Francesco Zallio, Elisabeth Vandenberghe, Stephen Robinson, Patrick J. Hayden, Ibrahim Yakoub-Agha, Silvia Montoto, Peter Dreger and on behalf of the European Society for Blood and Marrow Transplantation Lymphoma and Chronic Malignancies Working Parties

(c) The Author(s) 2021

Bone Marrow Transplantation (2021) 56:3108; https://doi.org/10.1038/s41409-021-01490-9

Correction to: Bone Marrow Transplantation https://doi.org/ 10.1038/s41409-020-0946-x, published online 22 May 2020

The article "Idelalisib exposure before allogeneic stem cell transplantation in patients with follicular lymphoma: an EBMT survey", written by Leopold Sellner, Johannes Schetelig, Linda Koster, Goda Choi, Didier Blaise, Dietrich Beelen, Fabrizio Carnevale Schianca, Jakob Passweg, Urs Schanz, Emmanuel Gyan, Federica Sora, Nicolaus Kröger, Gerald. G. Wulf, Gwendolyn Van Gorkom, Jiri Mayer, Corentin Orvain, Jean Henri Bourhis, Pavel Jindra, Victoria Potter, Francesco Zallio, Elisabeth Vandenberghe, Stephen Robinson, Patrick J. Hayden, Ibrahim Yakoub-Agha, Silvia Montoto, Peter Dreger, on behalf of the European Society for Blood and Marrow Transplantation Lymphoma and Chronic Malignancies Working Parties, was originally published Online First without Open Access. After publication in volume 55, issue 12 , page 2335-2338, the author decided to opt for Open Choice and to make the article an Open Access publication. Therefore, the copyright of the article has been changed to $\odot$ The Author(s) 2020 and the article is forthwith distributed under the terms of the Creative Commons Attribution 4.0 International License, which permits use, sharing, adaptation, distribution and reproduction in any medium or format, as long as you give appropriate credit to the original author(s) and the source, provide a link to the Creative Commons licence, and indicate if changes were made. The images or other third party material in this article are included in the article's Creative Commons licence, unless indicated otherwise in a credit line to the material. If material is not included in the article's Creative Commons licence and your intended use is not permitted by statutory regulation or exceeds the permitted use, you will need to obtain permission directly from the copyright holder. To view a copy of this licence, visit http://creativecommons.org/ licenses/by/4.0. Open access funding is enabled and organized by Projekt DEAL.

CC Open Access This article is licensed under a Creative Commons adaptation, distribution and reproduction in any medium or format, as long as you give appropriate credit to the original author(s) and the source, provide a link to the Creative Commons license, and indicate if changes were made. The images or other third party material in this article are included in the article's Creative Commons license, unless indicated otherwise in a credit line to the material. If material is not included in the article's Creative Commons license and your intended use is not permitted by statutory regulation or exceeds the permitted use, you will need to obtain permission directly from the copyright holder. To view a copy of this license, visit http://creativecommons. org/licenses/by/4.0/.

(c) The Author(s) 2021 